\title{
Pengendalian Penyakit Layu Stewart Pada Tanaman Jagung yang Ramah Lingkungan dengan Rizobakteri
}

\author{
I Gede Rai Maya Temaja, G.N. Alit Susanta Wirya, Ni Made Puspawati, dan \\ Muhammad Ikhsan Nulzaen
}

Universitas Udayana, Denpasar 80225; e-mail: raitemaja@unud.ac.id

\begin{abstract}
ABSTRAK
Penyakit layu stewart telah menimbulkan masalah besar bagi negara produsen jagung. Penyakit yang disebabkan oleh bakteri Pantoea stewartii subsp. stewartii ini pertama kali dilaporkan keberadaannya pada tanaman jagung di Bali yaitu pada tahun 2017. Kejadian penyakit baru pada komoditas penting seperti jagung, sangat urgen untuk dicarikan solusi pengendaliannya. Menyusun strategi pengendalian penyakit, harus mengacu pada pertanian berkelanjutan dengan mempertimbangkan keseimbangan dan keamanan lingkungan, kesehatan petani dan konsumen. Alternatif pengendalian yang yang merupakan tujuan penelitian ini adalah pemanfaatan rhizobakteria sebagai penginduksi ketahanan tanaman terhadap penyakit layu stewart. Penelitian rumah kaca dirancang menggunakan Rancangan Acak Kelompok (RAK) dengan pola faktorial dilakukan untuk menguji potensi rizobakteri sebagai agens penginduksi ketahanan tanaman jagung. Penelitian menggunakan dua faktor yaitu isolat rizobakteri (isolat TLKC, isolat $\mathrm{CgBd}$ dan tanpa isolat rizobakteri yaitu menggunakan air steril sebagai kontrol) dan cara apilkasinya (perendaman kecambah, perendaman akar bibit, dan penyiraman bibit). Variabel yang diamati adalah keparahan penyakit, pertumbuhan tanaman (tinggi tanaman dan jumlah daun), hasil (panjang dan berat tongkol per tanaman), total fenol dan kandungan asam salisilat. Perlakuan isolat rizobakteri CgBd yang diaplikasikan melalui perendaman kecambah merupakan perlakuan terbaik, karena memberikan pengaruh terhadap pertumbuhan tanaman yaitu tinggi tanaman tertinggi, jumlah daun terbanyak, dan produksi yaitu panjang dan berat tongkol yang tertinggi; dan keparahan penyakit terendah. Rendahnya keparahan penyakit karena tanaman jagung memiliki ketahanan yang meningkat terhadap penyakit layu stewart. Indikator peningkatan ketahanan jagung terhadap penyakit layu stewart adalah peningkatan kandungan total fenol dan asam salisilat. Penelitian menyimpulkan bahwa rizobakteri isolat CgBd dan TLKC mampu berperan sebagai agens penginduksi ketahanan sistemik dan sekaligus sebagai pemacu pertumbuhan tanaman; dan cara aplikasi rizobakteri yang terbaik adalah melalui perendaman kecambah jagung pada suspensi rizobakteri.
\end{abstract}

Kata kunci: jagung, Pantoea, rizobakteri, perendaman kecambah, keamanan lingkungan

\begin{abstract}
Stewart wilt disease has caused major problems for corn producing countries. Disease caused by Pantoea stewartii subsp. stewartii was first reported its existence on corn plants in Bali, in 2017. The incidence of new diseases on essential commodities such as corn, it is very urgent to look for its control solutions. Devise strategies for disease control, it should refer to sustainable agriculture by considering the balance and the environmental security, the health of farmers and consumers. An alternative control which is the purpose of this research is the utilization of rhizobakteria as inducers of plant resistance to stewart wilt disease. Greenhouse studies was designed using a randomized block design (RBD) with factorial pattern was conducted to test the potential rhizobakteria as inducer agents of plant resistance. The study was used two factors, namely: rizobakteri isolates (TLKC isolate, CgBd isolate and without rizobakteri isolates i.e. using sterile water as a control) and the way applications (soaking of sprouts, soaking of seedling root and watering the seeds). The variables measured were disease severity, plant growth (plant height and number of leaves), productions (length and weight of cobs per plant), phenols total and salicylic acid contents. Treatment of $\mathrm{CgBd}$ isolate applied trough sprouts soaking was the best treatment. It was giving the effects on plant growth, namely: the highest plant height and leaves number; production that were the highest of length and weight of cobs per plant; and the lowest disease severity. The low level of disease severity because the corn plants had increased resistance to stewart wilt disease. The indicator of increased corn resistance to stewart wilt disease was an increase in total content of phenols and salicylic acid. The study concluded that CgBd and TLKC rizobakteri isolates able to act as inducer agent of systemic resistance as well as plant growth promoters; and the best way of rizobakteri isolates application was through sprouts soaking on rizobakteri suspension.
\end{abstract}

Keywords: corn, Pantoea, rhizobakteria, sprouts soaking, environmental security

Citation: Temaja, I G. R.M., Wirya, G.N.A.S., Puspawati, N.M. dan Nulzaen. M.I. (2018). Pengendalian Penyakit Layu Stewart Pada Tanaman Jagung yang Ramah Lingkungan dengan Rizobakteri. Jurnal Ilmu Lingkungan, 16(1), 44-48, doi:10.14710/jil.16.1.44-48 
Temaja, I G. R.M., Wirya, G.N.A.S., Puspawati, N.M. dan Nulzaen. M.I. (2018). Pengendalian Penyakit Layu Stewart Pada Tanaman Jagung yang Ramah Lingkungan dengan Rizobakteri. Jurnal IImu Lingkungan, 16(1),44-48, doi:10.14710/jil.16.1.44-48

\section{Pendahuluan}

Penyakit layu stewart yang disebabkan oleh bakteri Pantoea stewartii subsp. stewartii merupakan penyakit tular benih yang sangat penting pada jagung. Freeman dan Pataky (2001) melaporkan bahwa pada jagung manis terjadi pengurangan hasil $0.8 \%$ untuk setiap insidensi penyakit $1 \%$ dari bibit tanaman terinfeksi sistemik oleh bakteri Pantoea stewartii subsp. stewartii.

Kejadian penyakit layu stewart Indonesia, dilaporkan pada tahun 2014 oleh Rahma et al. (2014) yaitu pada tanaman jagung di daerah Bogor, Jawa Barat. Gejala penyakit ini ditandai dengan perubahan warna daun dari hijau pucat ke kuning, disertai garis linear teratur atau tepinya bergelombang sejajar dengan tulang daun. Di Bali, gejala penyakit layu Stewart ditemukan pada jagung manis pada tahun 2015, dan dipastikan bahwa tanaman jagung manis di kota Denpasar yang menunjukkan gejala penyakit layu Stewart diinfeksi oleh bakteri $P$. stewartii subsp. stewartii (Temaja et al. 2017).

Dari kejadian ini, hal penting yang perlu mendapat perhatian dan tindak lajut adalah $P$. stewartii subsp. stewartii telah masuk ke Indonesia, dan merupakan kejadian penyakit baru pada komoditas penting seperti jagung, sehingga sangat urgen untuk mencari solusi pengendalian penyakit tersebut. Menyusun strategi pengendalian penyakit, harus mengacu pada pertanian berkelanjutan dengan mempertimbangkan keseimbangan dan keamanan lingkungan, kesehatan petani dan konsumen. Pengendalian penyakit tanaman selama ini lebih sering dilakukan dengan menggunakan pestisida kimia. Aplikasi pestisida kimia yang terus menerus memberikan dampak negatif bagi lingkungan, seperti matinya organisme berguna, kebalnya hama atau patogen, dan timbulnya hama atau patogen baru. Dampak lainnya adalah residu yang terbawa oleh tanaman akan sangat berbahaya bagi kesehatan konsumen, sehingga diperlukan alternatif pengendalian yang meminimalisasi penggunaan pestisida kimia. Pemanfaatan rizobakteria sebagai penginduksi ketahanan tanaman dapat dipakai sebagai alternatif pengendalian yang ramah lingkungan. Pemanfaatan rizobakteri untuk mengendalikan pathogen sudah banyak diteliti, diantaranya adalah Audenart et al. (2002) melaporkan bahwa isolat Pseudomonas aeruginosa 7NSK2 dapat mengendalikan Botrytis cineria pada tanaman tomat, dengan memproduksi antibiotika pyocyanin yang terlibat dalam induce systemic resistance. Pseudomonas dapat memproduksi antibiotika 2.4-diacetylphloroglucinol (DAPG) yang terbukti menstimulasi ketahanan terinduksi pada Arabidopsis thaliana dalam menekan patogen Peronospora parasitica (Lavicoli et al., 2003). Penelitian lain melaporkan bahwa perlakuan rizobakteri pada biji labu dapat meningkatkan ketahanan tanaman terhadap Zuccini yellow mosaic potyvirus (Shehata et al., 2008).
Tujuan penelitian ini adalah mengkaji pemanfaatan rhizobakteri sebagai penginduksi ketahanan tanaman jagung terhadap penyakit layu stewart. Aplikasi rizobakteria pada benih jagung diharapkan akan menginduksi ketahanan tanaman melalui mekanisme induksi ketahanan sistemik.

\section{Metode Penelitian}

\subsection{Uji potensi rizobakteri sebagai agens penginduksi ketahanan tanaman}

Pengujian potensi rizobakteri sebagai agens penginduksi ketahanan tanaman jagung dilakukan di rumah kaca. Penelitian dirancang menggunakan Rancangan Acak Kelompok (RAK) dengan pola faktorial (dua faktor). Faktor pertama adalah isolat rizobakteri, terdiri dari 3 jenis yaitu:

$$
\begin{aligned}
& \mathrm{K} \text { : air steril (kontrol) } \\
& \mathrm{T} \text { : rizobakteri isolat TLKC } \\
& \mathrm{M} \text { : rizobakteri isolat } \mathrm{CgBd}
\end{aligned}
$$

Faktor kedua adalah cara apilkasi rizobakteri, terdiri dari 3 jenis yaitu:
A : perendaman kecambah
B : perendaman akar bibit
C : penyiraman bibit

Sehingga ada 9 kombinasi perlakuan yaitu KA, KB, KC,TA, TB,TC, MA,MB, dan MC.

\subsection{Aplikasi Perlakuan.}

Media tanam dibuat dari campuran tanah dan pupuk kandang sebagai pupuk dasar $(2: 1 \mathrm{v} / \mathrm{v})$, kemudian campuran ini disterilisasi secara tyndalisasi didalam dandang dengan uap panas $100^{\circ} \mathrm{C}$. Bibit jagung disemaikan pada lapisan kapas basah dan ditutup lapisan kapas tipis selama 5 hari (sampai muncul kecambah). Perlakuan perendaman kecambah dan perendaman akar bibit dilakukan masing-masing pada saat bibit berkecambah dan pada bibit umur 14 hari setelah semai. Perendaman dilakukan selama 10 menit. Sedangkan perlakuan penyiraman bibit dengan suspensi rizobakteri dilakukan pada 7 hari setelah semai.

\subsection{Inokulasi $P$. stewartii subsp. stewartii secara Mekanis.}

Inokulasi Pantoea stewartii subsp.stewartii dilakukan pada saat tanaman jagung berumur 8 hari (Coplin \& Kado, 2001). Inokulasi pada pangkal batang dengan cara menginjeksikan suspensi bakteri Pantoea stewartii subsp.stewartii $\left(10^{8} \mathrm{CFU} / \mathrm{ml}\right)$ ke jaringan pembuluh tanaman jagung. Setelah diinokulasi tanaman ditutup dengan plastik untuk menjaga kelembaban.

\subsection{Pengamatan dan Analisis Data.}

Pengamatan dilakukan terhadap keparahan penyakit, tinggi tanaman, jumlah daun, panjang tongkol, berat tongkol per tanaman, total fenol dan kandungan asam salisilat. Data yang diperoleh selanjutnya dianalisis secara statistika dengan ANOVA (Analysis of Varians). Apabila perlakuan memberikan pengaruh yang nyata 
terhadap parameter yang diamati, dilanjutkan dengan uji beda rata-rata Duncans Multiple Range Test (DMRT) taraf 5\%.

Keparahan penyakit (KP) diukur menggunakan rumus:

$$
\mathrm{KP}=\frac{\sum_{i=1}^{k}\left(\mathrm{n}_{i} \times \mathrm{v}_{i}\right)}{\mathrm{N} \times \mathrm{V}} \times 100,
$$

$\mathrm{KP}$, keparahan penyakit (\%); $\mathrm{n}_{i}$, jumlah daun dari tiap kategori serangan; $\mathrm{V}_{i}$, nilai skala dari tiap kategori serangan (Tabel 1); N, jumlah daun yang diamati; $\mathrm{V}$, nilai kategori serangan tertinggi (Rahma et al. 2010).

Tabel 1 Parameter keparahan serangan P. stewartii subsp. stewartii pada tanaman jagung

\begin{tabular}{clll}
\hline Skala & Serangan & $\begin{array}{l}\text { Kreteria } \\
\text { serangan }\end{array}$ & Tingkat virulensi \\
\hline 1 & $<1 \%$ & Sehat & Avirulen \\
2 & $1 \%$ & Sangat ringan & Kurang virulen \\
3 & $2 \%$ & Sangat ringan & Kurang virulen \\
4 & $3 \%$ & Sangat ringan & Kurang virulen \\
5 & $4 \%$ & Sangat ringan & Kurang virulen \\
6 & $5-25 \%$ & Ringan & Virulen \\
7 & $25-50 \%$ & Sedang & Virulen \\
8 & $50-90 \%$ & Berat & Sangat virulen \\
9 & $>90 \%$ & Sangat berat & Sangat virulen \\
\hline
\end{tabular}

Sumber : Rahma et al. (2010)

\section{Hasil dan Pembahasan}

\subsection{Pengaruh Isolat Rizobakteri dan Cara} Aplikasinya terhadap Keparahan Penyakit

Hasil analisis statistika menunjukkan bahwa tidak terjadi interaksi perlakuan isolat rizobakteria dengan cara aplikasinya terhadap keparahan penyakit. Tetapi pengaruh faktor jenis isolat memberikan pengaruh yang sangat nyata $(P \leq 0,01)$ terhadap keparahan penyakit pada pengamatan minggu VII (Tabel 2). Keparahan penyakit layu stewart yang paling rendah pada minggu VII yaitu sebesar 13\% terjadi pada perlakuan isolat $\mathrm{CgBd}$ yang diaplikasikan melalui perendaman kecambah (MA), tidak berbeda nyata dengan perlakuan TA dan MB. Keparahan penyakit pada kontrol (KA, KB, dan $\mathrm{KC}$ ) rata-rata lebih tinggi dari perlakuan aplikasi isolat rizobakteri, dan tertinggi pada KA (tanpa pemberian isolat rizobakteri dan perendaman kecambah pada air steril). Perlakuan isolat $\mathrm{CgBd}$ yang diaplikasikan melalui perendaman kecambah (MA) memberikan perlindungan terbaik bagi tanaman jagung terhadap penyakit layu stewart, diikuti dengan perlakuan TA, dan MB.

Laju perkembangan penyakit layu stewart disajikan pada Gambar 1. Gejala penyakit layu stewart pada kontrol sudah terlihat pada umur tanaman 2 minggu dan terus meningkat sampai pengamatan terakhir (umur tanaman 7 minggu). Sedangkan pada perlakuan isolat rizobakteri, gejala penyakit layu stewart baru muncul pada umur tanaman 4 minggu, dengan keparahan penyakit yang lebih rendah daripada kontrol. Keparahan penyakit yang lebih rendah pada perlakuan isolat karena ketahanan yang terinduksi pada tubuh tanaman jagunng sebagai akibat kehadiran rizobakteri. Peningkatan ketahanan tanaman dapat diinduksi oleh agen penginduksi mikroorganisme non patogenik dan perlakuan kimia. Widnyana (2014) melaporkan bahwa rizobakteri Pseudomonas alcaligenes dapat menginduksi ketahanan tanaman tomat terhadap penyakit layu yang disebabkan oleh Fusarium oxysforum f.sp. lycopersicum.

Tabel 2. Pengaruh perlakuan isolat rizobakteri dan cara aplikasinya terhadap keparahan penyakit pada minggu VII

\begin{tabular}{cc}
\hline Perlakuan & Keparahan Penyakit (\%) \\
\hline KA & $30^{\mathrm{a}}$ \\
KB & $27^{\mathrm{ab}}$ \\
KC & $26^{\mathrm{abc}}$ \\
MA & $13^{\mathrm{e}}$ \\
MB & $18^{\mathrm{de}}$ \\
MC & $21^{\mathrm{bcd}}$ \\
TA & $17^{\mathrm{de}}$ \\
TB & $20^{\mathrm{cd}}$ \\
TC & $23^{\mathrm{bcd}}$ \\
\hline
\end{tabular}

Keterangan: Angka yang diikuti oleh huruf yang sama pada kolom yang sama adalah berbeda tidak nyata pada uji DMRT 5\%

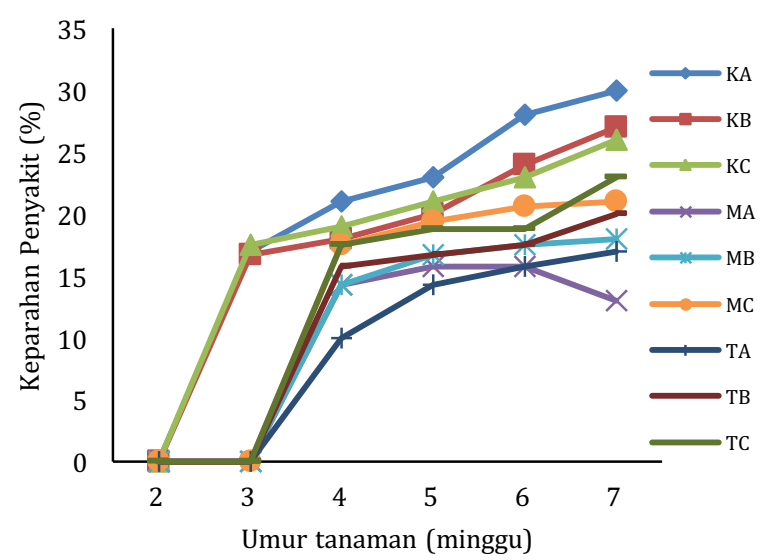

Gambar 1. Grafik pengaruh perlakuan isolat rizobakteria dan cara aplikasinya terhadap keparahan penyakit

\subsection{Pengaruh Isolat Rizobakteri dan Cara Aplikasinya terhadap Pertumbuhan dan Hasil Tanaman Jagung}

Hasil analisis statistika menunjukkan bahwa perlakuan isolat rizobakteri dan cara aplikasinya berpengaruh sangat nyata $(\mathrm{P} \leq 0,01)$ terhadap tinggi tanaman dan jumlah daun. Terdapat inetraksi nyata $(P \leq 0,05)$ antara perlakuan isolat rizobakteri dengan cara aplikasinya terhadap tinggi tanaman dan jumlah daun pada minggu VII (Tabel 3). Tanaman jagung tertinggi yaitu $141,37 \mathrm{~cm}$ pada perlakuan MA yaitu isolat $\mathrm{CgBd}$ yang diaplikasikan melalui perendaman kecambah, dikuti TA $(132,37 \mathrm{~cm})$ dan $\mathrm{MB}(123,23$ $\mathrm{cm})$. Perlakuan KA yaitu tanpa pemberian isolat rizobakteri dan perendaman kecambah pada air steril merupakan perlakuan dengan tinggi tanaman terendah yaitu rata-rata $96,27 \mathrm{~cm}$.

Jumlah daun terbanyak terjadi pada perlakuan dan perlakuan isolat $\mathrm{CgBd}$ yang diaplikasikan melalui perendaman kecambah (MA) dan perlakuan isolat TLKC yang diaplikasikan melalui 
perendaman kecambah (TA), diikuti oleh perlakuan isolat $\mathrm{CgBd}$ yang diaplikasikan melalui perendaman akar bibit (MB). Jumlah daun terendah yaitu 8,67 pada perlakuan tanpa pemberian isolat rizobakteri dan perendaman kecambah pada air steril (KA).

Tabel 3. Pengaruh perlakuan isolat rizobakteri dan cara aplikasinya terhadap tinggi tanaman dan jumlah daun jagung pada umur tanaman 7 minggu

\begin{tabular}{ccc}
\hline Perlakuan & Tinggi tanaman $(\mathrm{cm})$ & $\begin{array}{c}\text { Jumlah daun } \\
\text { (helai) }\end{array}$ \\
\hline KA & $96,27^{\mathrm{a}}$ & $8,67^{\mathrm{a}}$ \\
KB & $105,13^{\mathrm{ab}}$ & $9,33^{\mathrm{bb}}$ \\
KC & $106,63^{\mathrm{ab}}$ & $9,33^{\mathrm{ab}}$ \\
MA & $141,37^{\mathrm{d}}$ & $10,33^{\mathrm{c}}$ \\
MB & $128,03^{\mathrm{cd}}$ & $10,00^{\mathrm{bc}}$ \\
MC & $118,60^{\mathrm{bc}}$ & $9,67^{\mathrm{bc}}$ \\
TA & $132,37^{\mathrm{cd}}$ & $10,33^{\mathrm{c}}$ \\
TB & $123,23^{\mathrm{bcd}}$ & $9,67^{\mathrm{bc}}$ \\
TC & $113,63^{\mathrm{abc}}$ & $9,67^{\mathrm{bc}}$ \\
\hline
\end{tabular}

Keterangan: Angka yang diikuti oleh huruf yang sama pada kolom yang sama adalah berbeda tidak nyata pada uji DMRT $5 \%$

Perlakuan isolat rizobakteri CgBd dan TLKC memberikan pengaruh nyata $(\mathrm{P}<0,05)$ terhadap panjang dan berat tongkol. Terdapat pengaruh interaksi yang nyata $(\mathrm{P}<0,05)$ terhadap kedua variabel tersebut. Tabel 4 menunjukkan bahwa panjang tongkol tertinggi terdapat pada perlakuan isolat $\mathrm{CgBd}$ yang diaplikasikan melalui perendaman kecambah (MA) yaitu $16,5 \mathrm{~cm}$, tidak berbeda nyata dengan perlakuan TA, MB dan TB. Panjang tongkol terendah adalah pada perlakuan $\mathrm{KB}(13,03 \mathrm{~cm})$, tidak berbeda nyata dengan perlakuan KA dan KC. Berat tongkol tertinggi terdapat pada perlakuan isolat $\mathrm{CgBd}$ yang diaplikasikan melalui perendaman kecambah (MA) yaitu $130,77 \mathrm{~g}$, tidak berbeda nyata dengan perlakuan TA dan MB. Berat tongkol terendah adalah pada perlakuan $\mathrm{KB}(13,03 \mathrm{~cm})$, tidak berbeda nyata dengan perlakuan KA, KC dan TC.

Secara umum dapat dikatakan bahwa perlakuan isolat rizobakteri $\mathrm{CgBd}$ yang diaplikasikan melalui perendaman kecambah (MA) merupakan perlakuan yang memberikan panjang dan berat tongkol yang tertinggi dibandingkan dengan perlakuan lainnya, diikuti dengan perlakuan TA dan MB.

Tabel 4. Pengaruh perlakuan isolat rizobakteri dan cara aplikasinya terhadap panjang dan berat tongkol

\begin{tabular}{cll}
\hline Perlakuan & Panjang tongkol $(\mathrm{cm})$ & Berat tongkol $(\mathrm{g})$ \\
\hline KA & $13,97^{\mathrm{ab}}$ & $92,80^{\mathrm{ab}}$ \\
KB & $13,03^{\mathrm{a}}$ & $84,13^{\mathrm{a}}$ \\
KC & $13,76^{\mathrm{ab}}$ & $92,77^{\mathrm{ab}}$ \\
MA & $16,50^{\mathrm{d}}$ & $130,77^{\mathrm{d}}$ \\
MB & $15,60^{\mathrm{cd}}$ & $116,57^{\mathrm{cd}}$ \\
MC & $14,70^{\mathrm{bc}}$ & $99,23^{\mathrm{ab}}$ \\
TA & $15,80^{\mathrm{cd}}$ & $118,67^{\mathrm{cd}}$ \\
TB & $15,17^{\mathrm{bcd}}$ & $107,47^{\mathrm{bc}}$ \\
TC & $14,63^{\mathrm{bc}}$ & $96,10^{\mathrm{ab}}$
\end{tabular}

Keterangan: Angka yang diikuti oleh huruf yang sama pada kolom yang sama adalah berbeda tidak nyata pada uji DMRT $5 \%$
3.3. Pengaruh Isolat Rizobakteri dan Cara Aplikasinya terhadap Total Fenol dan Asam Salisilat

Tabel 5. menunjukkan bahwa peningkatan kandungan total fenol terjadi pada semua jenis isolat rizobakteri dan cara aplikasinya. Peningkatan yang paling tinggi terjadi pada perlakuan isolat $\mathrm{CgBd}$ yang diaplikasikan melalui perendaman kecambah (MA), diikuti dengan perlakuan isolat TLKC yang diaplikasikan melalui perendaman kecambah (TA). Kandungan total fenol pada perlakuan MA meningkat $248 \%$ dibandingkan dengan kontrol, pada TA meningkat 237\%.

Kecenderungan yang sama terjadi pada kandungan asam salisilat. Peningkatan kandungan asam salisilat terjadi pada semua jenis isolat rizobakteri dan cara aplikasinya. Peningkatan yang paling tinggi terjadi pada perlakuan isolat $\mathrm{CgBd}$ yang diaplikasikan melalui perendaman kecambah (MA), diikuti dengan perlakuan isolat TLKC yang diaplikasikan melalui perendaman kecambah (TA). Kandungan total fenol pada perlakuan MA meningkat 278\% dibandingkan dengan kontrol, pada TA meningkat $263 \%$. Hasil ini sesuai dengan pendapat De Meyer \& Hofte (1977) dan Maurhofer et al. (1998) yang menyatakan bahwa asam salisilat adalah metabolit tanaman sebagai respon terhadap Pseudomonas spp. yang menstimulasi ketahanan tanaman. Fenol juga dipakai sebagai indikator peningkatan ketahanan sistemik terinduksi sebagai respon infeksi mikroorganisme non patogenik, disamping senyawa-senyawa lain seperti enzim $\beta-1.3$ glukanase, kitinase, $\beta-1.4$ glukosidase, citonase, peroksidase dan asam salisilat (Maurhofer et al. 1994; Wei et al. 1996).

Tabel 5. Kandungan total fenol dan asam salisilat jaringan tanaman jagung setelah aplikasi isolat rizobakteri

\begin{tabular}{ccccc}
\hline $\begin{array}{c}\text { Perla- } \\
\text { kuan }\end{array}$ & $\begin{array}{c}\text { Total } \\
\text { fenol } \\
(\%)\end{array}$ & $\begin{array}{c}\text { Peningkatan } \\
(\%)\end{array}$ & $\begin{array}{c}\text { Asam } \\
\text { salisilat } \\
(\%)\end{array}$ & $\begin{array}{c}\text { Peningkatan } \\
(\%)\end{array}$ \\
\hline KA & $0,27^{\mathrm{a}}$ & & $0,18^{\mathrm{a}}$ & \\
KB & $0,29^{\mathrm{a}}$ & & $0,21^{\mathrm{b}}$ & \\
KC & $0,29^{\mathrm{a}}$ & & $0,20^{\mathrm{ab}}$ & \\
MA & $0,94^{\mathrm{e}}$ & 248 & $1,02^{\mathrm{g}}$ & 278 \\
MB & $0,82^{\mathrm{c}}$ & 183 & $0,87^{\mathrm{d}}$ & 200 \\
MC & $0,74^{\mathrm{b}}$ & 155 & $0,78^{\mathrm{c}}$ & 169 \\
TA & $0,91^{\mathrm{d}}$ & 237 & $0,98^{\mathrm{f}}$ & 263 \\
TB & $0,82^{\mathrm{c}}$ & 183 & $0,92^{\mathrm{e}}$ & 217 \\
TC & $0,76^{\mathrm{b}}$ & 162 & $0,78^{\mathrm{c}}$ & 169 \\
\hline
\end{tabular}

Keterangan: Angka yang diikuti oleh huruf yang sama pada kolom yang sama adalah berbeda tidak nyata pada uji DMRT $5 \%$

Perlakuan isolat rizobakteri $\mathrm{CgBd}$ yang diaplikasikan melalui perendaman kecambah (MA) merupakan perlakuan terbaik, karena memberikan pengaruh terhadap pertumbuhan tanaman yaitu tinggi tanaman tertinggi, jumlah daun terbanyak, dan produksi yaitu panjang dan berat tongkol yang tertinggi; dan keparahan penyakit terendah. Perlakuan MA berbeda tidak nyata dengan perlakuan isolat rizobakteri TLKC yang diaplikasikan melalui perendaman kecambah (TA) dan perlakuan isolat 
rizobakteri $\mathrm{CgBd}$ yang diaplikasikan melalui perendaman akar bibit (MB). Pertumbuhan dan hasil terbaik pada perlakuan MA sebagai akibat keparahan penyakit paling rendah dibandingkan dengan perlakuan lainnya. Rendahnya keparahan penyakit karena tanaman jagung memiliki ketahanan yang meningkat terhadap penyakit layu stewart. Indikator peningkatan ketahanan jagung terhadap penyakit layu stewart adalah peningkatan kandungan total fenol dan asam salisilat pada perlakuan tersebut. Hasil penelitian yang serupa ditemukan oleh Widnyana et al. (2013), yaitu adanya peningkatan total fenol dan asam salisilat pada jaringan tanaman tomat yang diinfeksikan dengan rizobakteri Pseudomonas alcaligenes, berakibat pada peningkatan ketahanan tanaman terimbas secara sistemik terhadap penyakit layu yang disebabkan oleh Fusarium oxysforum f.sp. lycopersicum.

\section{Kesimpulan}

Rizobakteri isolat CgBd dan TLKC mampu berperan sebagai agens penginduksi ketahanan sistemik pada tanaman jagung terhadap penyakit layu stewart dan sekaligus sebagai pemacu pertumbuhan tanaman (Plant Growth Promoting Rhizobacteria/ PGPR). Isolat $\mathrm{CgBd}$ pemberikan penghambatan perkembangan penyakit, pertumbuhan dan hasil tanaman yang lebih baik daripada isolat TLKC. Cara aplikasi isolat yang terbaik adalah melalui perendaman kecambah jagung pada suspensi rizobakteri. Kedua isolat rizobakteri ini bisa dipakai sebagai alternatif pengendalian penyakit layu stewart pada tanaman jagung yang ramah lingkungan.

\section{Ucapan terima kasih}

Penelitian ini dibiayai oleh Direktorat Riset dan Pengabdian Masyarakat Direktorat Jendral Penguatan Riset dan Pengembangan Kementerian Riset, Teknologi, dan Pendidikan Tinggi melalui skema penelitian Fundamental dengan Kontrak Penelitian Nomor: 415.58/UN.14.4.A/ PL/2017, tanggal 30 Maret 2017.

\section{Daftar Pustaka}

Audenart, Pattery K.T., Cornelis P., and Hofte M., (2002), Induction of systemic resistance to Botrytis cinerea in tomato by Pseudomonas aeruginosa 7NSK2: role of salicylic acid, pyochelin, and pyicyanin. Mol. Plant-Microbe Interact. 15:1147-1156.

Coplin, D.L., and Kado C.I. (2001), Pantoea. in: Laboratory Manual for the Identification of Plant Pathogenic Bacteria. Third Edition. N. Schhaad, J. Jones, and W. Chun. Eds. American Phytopathological Sociaty Press, StPaul, MN. Pp. 73-83

De Meyer, G. and Hofte M., (1997), Salicylic produce by the rhizobacterium $P$. aeruginosa 7NSK2 induces resistence to leaf infection by Botrytis ceneria on bean. Phytopathology 87:588593.
Freeman N.D., and Pataky J.K. (2001), Levels of Stewart's wilt resistance necessary to prevent reductions in yield of sweet corn hybrids. Plant Dis. 85:1278-1284.

Lavicoli A., Boutet E., Buchala A., and Metraux J.P. (2003), Induce systemic resistance in Arabidopsis thaliana in response to root inoculation with Pseudomonas fluorescens CHA0. Mol. PlantMicrobe Interact. 16:851-858.

Maurhofer M., Hase C., Meuwly P., Metraux J.P., and Defago G. (1994), Induction of systemic resistance of tobacco to tobacco necrosis virus gy the root-colonizing Pseudomonas fluorescens stran CHAO: influence of the gacA gene and of pyoverdine production. Phytopathology 84:139-146.

Maurhofer M., Reimmann C., Sacherer S.P., Heeb S., Haas D., and Defago G. (1998), Salicylic acid biosynthesis genes expressed in Pseudomonas fluorescens Strain P3 improve the induction of systemic resistance in tobacco against tobacco necrosis virus. Phytopathology 88:678-684.

Rahma H., Nurbailis, Liswarni Y., dan Puspita Y. (2010), Uji virulensi beberapa isolat Pantoea stewartii penyebab layu stewart pada bibit jagung (Zea mays L). Manggaro. 11(1): 12-17.

Rahma H., Sinaga M.S., Surahman M., and Giyanto (2014), First report of Stewart's wilt of maize caused by Pantoea stewartii subsp. stewartii in Bogor district, Indonesia. J. ISSAAS 20(2):131-141.

Temaja I G.R.M., Wirya G.N. A. S., Puspawati N.M., and Syahdu K.N. (2017), Penyakit Layu Bakteri Stewart pada Jagung di Bali. Jurnal Fitopatologi Indonesia 13(5):184-190.

Wei G., Klopper J.W., and Tuzun S. (1996), Induce systemic resistance to cucumber diseases and and increase plant growth by plant growth promoting rhizobacteria (PGPR) under field conditions. Phytopathology 86:221-224.

Widnyana K., Suprapta D. N., Sudana I M., and Temaja I G.R.M., (2013), Pseudomonas alcaligenes, Potential Antagonist Against Fusarium oxysporum f.sp. lycopersicum the Cause of Fusarium Wilt Disease on Tomato. Journal of Biology, Agriculture and Healthcare 3(7):163-169.

Widnyana K., (2014), Pemanfaatan Rhizobakteri Pseudomonas spp. untuk Mengendalikan Penyakit Layu Fusarium pada Tanaman Tomat. Disertasi. Universitas Udayana. 